\title{
SOUTHERN RHODESIA
}

Owing to the fact that I was passing through Salisbury en route for Lusaka, I took the opportunity of visiting Ngomahuru again. Dr. Morris, the Secretary for Health for Southern Rhodesia very kindly arranged transport for me, and I was met at the plane on arrival and motored at once the 200 miles to Ngomahuru near Fort Victoria, arriving about 8.30 p.m. that same night.

I was extremely glad of this opportunity to revisit Ngomahuru, it was twenty-three years since my last visit and at that time the institution was in its infancy. The change since my first visit has been very great. I consider that this institution is a model of its kind and should be developed in every way possible as a Central Teaching Institution for the new Federation of Southern Rhodesia, Northern Rhodesia, and Nyasaland. The credit for the development of this leprosarium goes not only to the far-sighted policy of the Health Department, but to Dr. Mostert whose excellent work and inspiring leadership has made these developments possible.

On the morning of December '8th I was shown quickly round the institution, and then spent several hours seeing cases and discussing clinical problems. I was particlarly pleased to meet $\mathrm{Dr}$. 
Allen, who not only is keen, but is interested in histopathology. I was able to take several photographs and Dr. Mostert and Dr. Allen kindly said they would send me material from these cases. This biopsy material arrived later in London, and reports have been sent with copies of the slides. I was extremely gratified to see the records and methods of assessing cases, and I consider Ngomahuru an institution which is well equipped for clinical and therapeutic trials. I am hoping to be kept in touch with developments, and look forward to co-operation and collaboration with these workers. This institution has great potentialities.

I would express my personal gratitude to Dr. Mostert for enabling me to get a rapid insight into his problems, and to the Southern Rhodesian Government for their courtesy in making this visit possible.

Now that federation is an accepted fact, and because Nyasaland and Northern Rhodesia both have progressive leprosy policies, the time has come to integrate the leprosy campaign in this federation, and Ngomohuru has great claim to be the Central Training Institution for these territories, and any assistance towards the completion of a comprehensive anti-leprosy campaign centering on Ngomahuru as the Central Training and Research Institute will, I am sure, have the whole-hearted support of BELRA, and I shall watch with great interest and expectancy the future development of leprosy in these territories.

My tour through East and Central Africa was very stimulating, instructive and profitable, and to all who made this tour a success I express my deep sense of appreciation and gratitude. 